\title{
Characterization of organic matter in bottom sediments of Ivashkina Lagoon, Laptev Sea
}

\author{
Elena Gershelis ${ }^{1, *}$, Ivan Goncharov ${ }^{1}$, Oleg Dudarev ${ }^{1,2}$, Alexey Ruban $^{1}$, Igor Semiletov ${ }^{1,2}$ \\ ${ }^{1}$ National Research Tomsk Polytechnic University, 30, Lenin Avenue, Tomsk, 634050, Russia \\ ${ }^{2}$ Pacific Oceanological Institute, Russian Academy of Sciences, Vladivostok, 690041, Russia
}

\begin{abstract}
Here we present lithological and geochemical characteristics of the core drilled in coastal part of the Laptev Sea (Ivashkina Lagoon, Bykovsky Peninsula). It is shown that for sediments accumulated in specific lagoon conditions the increased content of organic carbon is confined to fine-grained lacustrine and lagoonal sediments in the uppermost layers. Pyrolytic analysis results indicate a sharp variability in the content of total organic carbon and volatile organic compounds across the studied horizons. The distribution of $n$-alkanes is characterized by the dominance of high molecular weight homologues, which indicates the ubiquitous contribution of higher terrestrial vegetation discharged with river and coastal thermo abrasion fluxes to the organic matter of bottom sediments.
\end{abstract}

\section{Introduction}

The interactions between climate and carbon cycle in the Arctic region are undergoing substantial changes due to destabilization of vulnerable permafrost carbon pool followed by massive thaw-release of organic carbon. This process triggers many complex biogeochemical mechanisms including intensive mobilization and increasing supply of terrigenous organic carbon to the coastal ocean, which have been the subject of growing scientific interest in recent years [1-2]. Organic matter (OM) contained in bottom sediments on the continental shelf accumulates heterogeneous signals of various processes of carbon transport and transformation and therefore acts as a unique indicator of its sources. Sedimentological and geochemical instruments allow us to obtain important information on potential input of both allochthonous and autochthonous components to organic matter contained in coastal surface sediments.

In present study we investigate bottom sediments accumulated in the specific lagoon conditions of the coastal part of the Laptev Sea (Ivashkina Lagoon, Bykovsky Peninsula).A core was collected from the well drilled in the central part of the Ivashkina lagoon (VD-13) as part of the 2013 spring research expedition. Here we focus on the uppermost layers, using grain-size, pyrolytic and GC-MS analyses.

${ }^{*}$ Corresponding author: elenapanova@tpu.ru 


\section{Methods}

Core sampling from the VD-13 well was carried out using the URB-4T exploratory drilling unit as described by [3].Grain size composition was determined using a laser microanalyser (Analysette 22, Fritsch) in the Arctic Research Laboratory (POI FEB RAS). Lithological classifications based in the three-component classification according to the content of sand fractions $(1-0.1 \mathrm{~mm})$, silt $(0.1-0.01 \mathrm{~mm})$ and clay $(<0.01 \mathrm{~mm})$.

The total content of organic carbon, the content of volatile organic compounds, the amount of biogeopolymers degradation products were determined on a Rock-Eval 6 Turbo pyrolyzer (VINCI Technologies). Samples were first pyrolised from $200{ }^{\circ} \mathrm{C}$ to $650{ }^{\circ} \mathrm{C}$ at a rate of $25{ }^{\circ} \mathrm{C} / \mathrm{min}$. Analysis of the extracts was performed by gas chromatography-mass spectrometry using a Bruker SCION 436 GC TQ instrument using an HP-5MS quartz capillary column (length $30 \mathrm{~m}$, internal diameter $0.25 \mathrm{~mm}$, film thickness $0.25 \mu \mathrm{m}$ ).

\section{Results and discussion}

Ivashkina lagoon is a former thermokarst lake transformed into a lagoon through the thermo abrasion of the runoff channel during marine transgression in Early Holocene[4]. The uppermost interval at first $1.5-2 \mathrm{~m}$ of the studied core is characterised by fine-grained deposits formed under lacustrine and lagoonal conditions. Alternations between siltdominated and sand-dominated taberites - thawed Late Neopleistocene Ice Complex deposits - appear deeper in the core, at the 3.7-11 m depth. They were compacted in a lake talik and redeposited in situ after primary thermokarst lake had been formed in early Holocene. Taberites composition remained unchanged but the structure was affected by thawing and compaction. Deposits underlying the taberites are comprised mainly of sanddominated sediments with contributions of both silt and detritus which are presumably of alluvial origin and probably have Mid-Pleistocene age.

According to the pyrolysis data (Table 1), the highest content of organic carbon (TOC) is observed at 1.59-2.4 m depth. TOC unevenly decreases with increasing depth; a sharp spike is observed at 5.58-6.94 $\mathrm{m}$ depth.

Table 1. Rock-Eval and GC-MS analysis data.

\begin{tabular}{|c|c|c|c|c|c|c|c|}
\hline $\begin{array}{c}\text { Sampling } \\
\text { depth, cm }\end{array}$ & $\begin{array}{c}\text { S1, } \\
\mathbf{m g} / \mathbf{g}\end{array}$ & $\begin{array}{c}\mathbf{S 2 ,} \\
\mathbf{m g} / \mathbf{g}\end{array}$ & $\begin{array}{c}\text { Tmax, } \\
{ }^{\circ} \mathbf{C}\end{array}$ & $\begin{array}{c}\text { HI, } \\
\mathbf{m g} / \mathbf{g}\end{array}$ & $\begin{array}{c}\text { OI, } \\
\mathbf{m g} / \mathbf{g}\end{array}$ & $\begin{array}{c}\text { TOC, } \\
\text { \% } \mathbf{~ w t}\end{array}$ & CPI \\
\hline 36 & 0.20 & 2.17 & 423 & 108 & 167 & 2.00 & 4.65 \\
\hline 159 & 0.21 & 2.52 & 424 & 108 & 175 & 2.33 & 5.99 \\
\hline 240 & 0.22 & 3.43 & 429 & 154 & 160 & 2.23 & 4.18 \\
\hline 390 & 0.12 & 2.78 & 424 & 150 & 193 & 1.85 & 4.41 \\
\hline 558 & 0.06 & 1.33 & 421 & 100 & 302 & 1.33 & 3.84 \\
\hline 694 & 0.00 & 0.04 & - & 10 & 349 & 0.41 & - \\
\hline 827 & 0.00 & 0.15 & - & 28 & 283 & 0.54 & - \\
\hline 940 & 0.00 & 0.06 & - & 20 & 450 & 0.30 & - \\
\hline 1023 & 0.00 & 0.11 & - & 16 & 639 & 0.67 & - \\
\hline 1126 & 0.00 & 0.06 & - & 11 & 156 & 0.55 & - \\
\hline 1228 & 0.06 & 0.57 & - & 57 & 151 & 0.96 & - \\
\hline 1290 & 0.00 & 0.00 & - & 0 & 433 & 0.09 & - \\
\hline
\end{tabular}




\begin{tabular}{|l|l|l|l|l|l|l|l|}
\hline 1405 & 0.00 & 0.09 & - & 24 & 145 & 0.38 & - \\
\hline 1524 & 0.00 & 0.00 & - & 0 & 353 & 0.15 & - \\
\hline 1624 & 0.00 & 0.00 & - & 0 & 325 & 0.08 & - \\
\hline 1710 & 0.00 & 0.00 & - & 0 & 455 & 0.11 & - \\
\hline 1790 & 0.01 & 0.00 & - & 0 & 468 & 0.19 & - \\
\hline
\end{tabular}

Note: TOC - total organic carbon (amount of organic carbon), \% by weight; S1 - amount of volatile $\left(300{ }^{\circ} \mathrm{C}\right)$ organic compounds, $\mathrm{mg} / \mathrm{g}$ of rock; S2 - amount of volatile organic matter degradation products, mg/g of rock; HI - hydrogen index S2x100/TOC, mg of degradation products/g of organic carbon. CPI - carbon preference index

The increased TOC and HI values in the upper most clay-dominated layers indicate reducing conditions of sedimentation occurring in lacustrine and lagoon environment (Fig.1a, b). Increases in OI corresponding to the TOC decreases indicate ancient alluvial or fluvial deposits (Fig.1a, c). This variability of TOC, HI and OI observed within the core apparently reflects uneven distribution of organic matter in laminated alluvial layers.

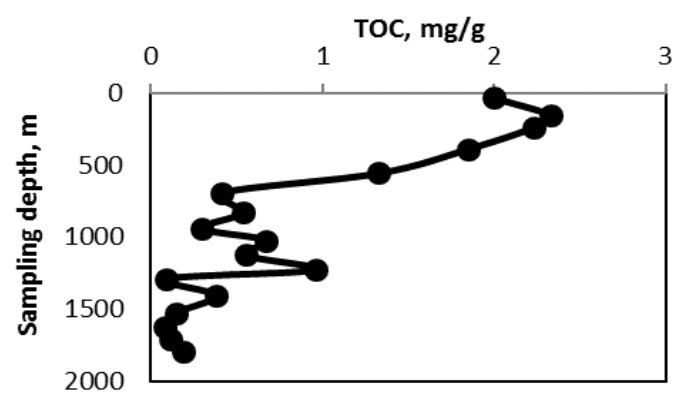

a

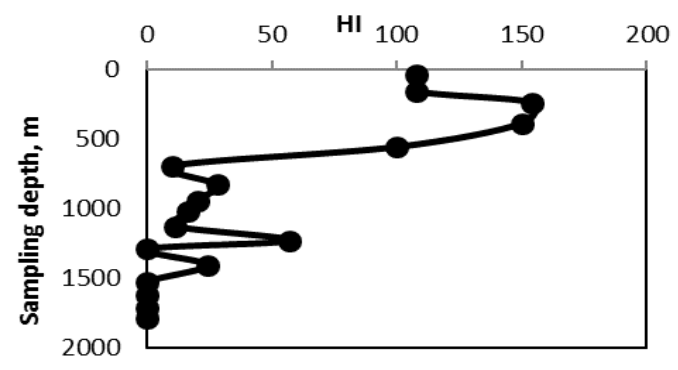

b

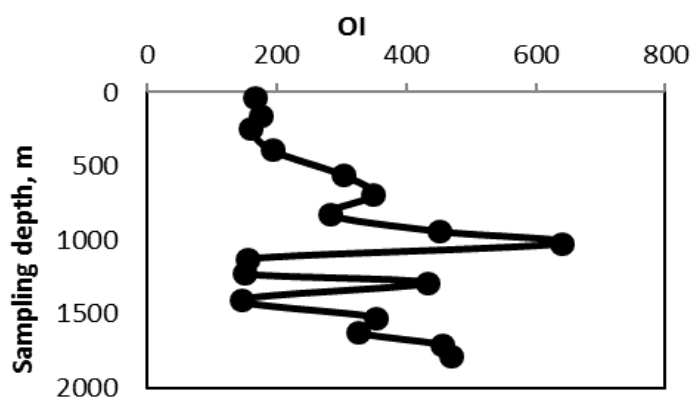

c

Fig. 1 Correlation of TOC (a), hydrogen (HI) (b) and oxygen (OI) (c) indices and depth (cm). 
Samples from the uppermost horizons $(0.36-5.58 \mathrm{~m}$ depth) were selected for the GCMS analysis, since they found to contain sufficient quantities of volatile organic compounds (S1, Table 1). Obviously, terrestrial input is a main contributor to the organic component of the studied sediments. High molecular weight (HMW) n-alkanes dominated by $\mathrm{C}_{27}, \mathrm{C}_{29}$, $\mathrm{C}_{31}$ with a distinct odd-over-even carbon prevalence act as markers of higher terrestrial vegetation coming with river discharge and thermo abrasion material. Even middle- and low molecular weight homologues formed as a result of bacterially-mediated HMW nalkanes transformation indicate the autochthonous biogenic component. High values of Carbon Preference Index (CPI) ( $>>3$ ) within the core overall show a prevalence of vascular land plants as a source of organic matter and minor microbial degradation. The highest index value is observed at $1.5-2 \mathrm{~m}$ depth interval which is composed predominantly of finegrained lacustrine and lagoonal sediments.

\section{Conclusion}

According to the initial results, a sharp variability in the content of organic carbon and volatile organic compounds along the studied core was revealed. Increased organic carbon content is confined to the fine-grained lacustrine and lagoonal sediments, whereas overall variability in organic carbon content might be caused by uneven distribution of organic matter in laminated alluvial layers. The n-alkanes distribution is characterized by the dominance of high molecular weight homologues, which indicates the ubiquitous contribution of higher terrestrial vegetation discharged with river and coastal thermo abrasion fluxes to the organic matter accumulated in surface sediments.

This study was funded by the Russian Science Foundation (\#15-17-20032 to NS) and Russian Foundation for Basic Research (\#18-35-00572 mol_a to EG).

\section{References}

1. I. Semiletov, I. Pipko, Ö. Gustafsson, L.G. Anderson, V. Sergienko, S. Pugach, O. Dudarev, A. Charkin, A. Gukov, L. Bröder, A. Andersson, E. Spivak, N. Shakhova. Nat. Geosci. 9, 361-365 (2016)

2. J.E. Vonk, I.P.Semiletov, O.V.Dudarev, T.Eglinton, A.Andersson, N.Shakhova, A. Charkin, B. Heim, Ö Gustafsson. J Geophys Res-Oceans 119, 8410-8421(2014)

3. N. Shakhova, I. Semiletov, O. Gustafsson, V. Sergienko, L. Lobkovsky, O. Dudarev, V. Tumskoy, M. Grigoriev, A. Mazurov, A. Salyuk, R. Ananiev, A. Koshurnikov, D. Kosmach, A. Charkin, N. Dmitrevsky, V. Karnaukh, A. Gunar, A. Meluzov and Chernykh D. Nat. Comm.8, 15872 (2017)

4. Romanovskii, H.-W.Hubberten, A.V.Gavrilov, V.E.Tumskoy, G.S.Tipenko, G., M.N. Grigoriev, C.Siegert. Permafr. Periglac. Process.11 (2), 137-152 (2000) 